\title{
APLIKASI CERDAS CERMAT ONLINE REALTIME UNTUK SEKOLAH DASAR
}

\author{
Mohamad Nurkamal Fauzan ${ }^{\text {**, Widia Resdiana }}{ }^{1}$, Dini Hamidin ${ }^{1}$ \\ Jurusan Teknik Informatika - Politeknik Pos Indonesia \\ Jalan Terusan Sariasih No 54 Bandung \\ E-mail: m.nurkamal.f@poltekpos.ac.id,widiaresdiana@poltekpos.ac.id, dinihamidin@poltekpos.ac.id \\ *Korespondensi penulis
}

\begin{abstract}
Abstrak: Berbagai macam aplikasi open source menjadi peluang untuk dapat menciptakan aplikasi permainan yang bernilai positif bagi perkembangan kecerdasan anak Sekolah Dasar (SD) dan dapat digunakan untuk berkompetisi dan berprestasi dalam hal wawasan ilmu pengetahuan. Kegiatan cerdas cermat pendidikan dasar khususnya pada tingkat SD menjadi objek potensial dalam pemanfaatan teknologi berbasis open source. Aplikasi cerdas cermat online realtime untuk Sekolah Dasar merupakan salah satu perangkat teknologi untuk bermain, berkompetisi, dan berprestasi, sebagai sarana meningkatkan ilmu pengetahuan siswa di tingkat pendidikan dasar. Aplikasi berbasis web ini dibangun dengan menggunakan metode prototipe. Hasil penelitian ini adalah 1) Requirement aplikasi untuk permainan cerdas cermat online ini berdasarkan tiga requirement, yaitu teknik menjawab pertanyaan secara realtime, leveling, dan banyak pengguna; 2) Aplikasi cerdas cermat online realtime ini diimplementasikan di dalam fungsi pertanyaan babak rebutan; 3) Perilaku kompetisi yang diterapkan dalam aplikasi cerdas cermat online realtime dapat digunakan untuk meningkatkan motivasi belajar, pengetahuan dan kompetisi siswa SD dalam ruang lingkup yang lebih luas. Aplikasi yang telah dibangun dapat dikembangkan lagi dengan menambahkan fitur leveling yang sudah ada dengan semua tingkatan kelas di sekolah dasar dan progress peningkatan kemampuan pengetahuan pengguna. Monitoring ini dapat digunakan sebagai nilai tambah dan penghargaan (reward) bagi sekolah maupun masyarakat kepada para siswa yang berkompetisi di dalamnya, dan sebagai dasar pengembangan bahan ajar guru.
\end{abstract}

Kata kunci: Cerdas cermat, online, realtime, sekolah dasar

\begin{abstract}
Many open source applications have created the opportunities to produce game applications with positive values for the developments of elementary students' intelligence and can be used for competition and achievement in the area of science and knowledge. Quiz activities for the level of elementary school have been the potential objects for the use of open source technology. The application of real time online quiz for elementary school is one of the sets of technology to play, compete, and achieve, as a means of improving students' knowledge in the level of elementary school. This web based application was established using prototype method. The results of the study are, 1) The application requirements for this online quiz game based on three requirements, which are the technique of real time answers, levelling, and multi users. 2) The application of real time online quiz is implemented in the functions of speed round 3) The competitive behaviour applied in the application of real time online quiz can also be applied to improve the motivation to study, knowledge and competition among students of elementary school in a wider context. The established application can be further developed by adding the existed levelling feature with all the grades in elementary school and the progress of user's knowledge improvement. The monitoring can be used as an added value and reward from schools or societies to students who compete in the quiz, and as basis of teachers' material development.
\end{abstract}

Keywords: Quiz, online, realtime, elementary school.

\section{PENDAHULUAN}

Permainan cerdas cermat telah banyak dikenal oleh seluruh masyarakat Indonesia, terutama di kalangan siswa sekolah. Permainan cerdas cermat ini merupakan permainan adu kepintaran baik dalam pengetahuan umum maupun pengetahuan yang dipelajari di sekolah.

Menumbuhkan minat belajar siswa melalui pendekatan permainan lebih efektif dan lebih memotivasi dalam menumbuhkan keingintahuan dan pengalaman dalam bermain cerdas cermat dibanding- kan dengan yang bukan dalam bentuk permainan. Permainan yang melibatkan pendidikan dapat dimanfaatkan sebagai lingkungan belajar yang efektif dan memotivasi bagi siswa [10]

Permainan cerdas cermat ini biasanya dilakukan dari mulai pertanyaan yang diajukan secara bergiliran sampai akhirnya saling berebut untuk menjawab pertanyaan. Teknologi informasi yang berkembang saat ini telah memungkinkan cerdas cermat dilakukan secara realtime. Sehingga, memungkinkan untuk sekelompok siswa menekan tombol menjawab pertanyaan pada saat yang bersamaan tanpa harus dalam 
lokasi yang sama dalam satu permainan cerdas cermat. Teknologi informasi realtime menjadi peluang permainan cerdas cermat untuk dapat dikombinasikan dengan kegiatan belajar mengajar siswa. Kombinasi keduanya dapat memberikan motivasi yang kuat bagi siswa dan membantu untuk meningkatkan kinerja mereka [11].

Berdasarkan paparan di atas, maka dalam paper ini akan membahas pengembangan aplikasi cerdas cermat online realtime untuk Sekolah Dasar (SD) berbasis web dengan teknologi open source. Aplikasi cerdas cermat ini dirancang dapat meningkatkan minat belajar dan kompetisi di antara siswa.

Tujuan dari pembuatan aplikasi ini adalah mengembangkan aplikasi permainan cerdas cermat berbasis web online realtime dengan menggunakan teknologi open source. Aplikasi ini dapat digunakan untuk banyak siswa sebagai peserta dan juga dapat digunakan untuk meningkatkan minat belajar dan kompetisi siswa SD.

\section{PEMBAHASAN}

\section{Metode Pengembangan Aplikasi Cerdas Cermat}

Metode yang digunakan dalam pengembangan aplikasi cerdas cermat ini menggunakan metode prototyping. Ketidakjelasan requirement aplikasi cerdas cermat yang dapat digunakan untuk evaluasi belajar dan meningkatkan kompetisi di antara siswa serta terbatasnya pengolahan data dala aplikasi cerdas cermat menjadi kendala untuk mengetahui requirement secara jelas. Penggunaan metode prototyping ini memungkinan requirement diketahui melalui pengalaman interaksi pengguna dengan prototipe [7, 12].

Tahapan pengembangan aplikasi cerdas cermat online realtime adalah sebagai berikut:

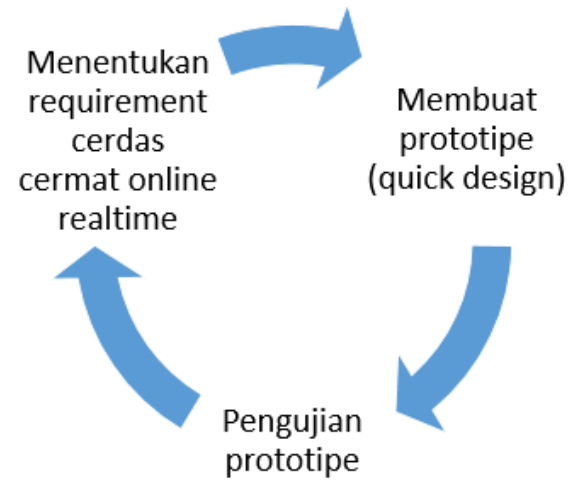

Gambar 1. Tahap pengembangan aplikasi cerdas cermat online realtime

\section{Menentukan Requirement}

Berdasarkan hasil penelitian seperti mengacu kepada tinjauan pustaka, penelitian ini lebih mengarah pada tujuan peningkatan pengetahuan, motivasi be- lajar dan kompetisi anak usia sekolah dasar melalui teknik cerdas cermat online realtime. Sehingga requirement aplikasi ini menitikberatkan pada teknologi dan teknik cerdas cermat online realtime yang terkait:
a. Teknik menjawab pertanyaan secara realtime
b. Leveling
c. Banyak pengguna

\section{Membuat Prototipe (Quick Design)}

Sesuai dengan identifikasi kebutuhan teknik cerdas cermat online realtime, selanjutnya dilakukan pembuatan prototipe dan quick design. Aktivitas yang dilakukan sebagai berikut:

a. Merancang arsitektur sistem

b. Merancang tampilan dan antarmuka aplikasi

c. Membuat prototipe

2. Tahap Pengujian

Tahap pengujian ini dilakukan untuk meningkatkan keakuratan identifikasi requirement aplikasi cerdas cermat online realtime.

\section{Teknik Cerdas Cermat Sekolah Dasar}

Sekolah dasar (disingkat SD) adalah jenjang paling dasar pada pendidikan formal di Indonesia. Sekolah dasar ditempuh dalam waktu 6 tahun, mulai dari kelas 1 sampai kelas 6. Lulusan sekolah dasar dapat melanjutkan pendidikan ke Sekolah Menengah Pertama (atau sederajat). Pelajar sekolah dasar umumnya berusia 7-12 tahun. Di Indonesia, setiap warga negara berusia 7-15 tahun tahun wajib mengikuti pendidikan dasar, yakni sekolah dasar (atau sederajat) 6 tahun dan sekolah menengah pertama (atau sederajat) 3 tahun [1].

Salah satu kegiatan yang sering diselenggarakan tingkat SD adalah cerdas cermat. Kegiatan cerdas cermat tersebut tersebut biasanya melibatkan banyak sekolah baik di wilayah 1 kota maupun tingkatan nasional (Indonesia). Cerdas cermat adalah pertandingan adu ketajaman berpikir dan ketangkasan menjawab (seperti pertanyaan bahasa, soal matematika, fisika dan lainnya) secara cepat dan tepat [2]. Teknik cerdas cermat juga merupakan jenis teknik yang dapat meningkatkan keaktifan berbicara seseorang termasuk pada siswa [4]. Penggunaan teknik cerdas cermat dalam pembelajaran berbicara dapat meningkatkan kemampuan mengajukan pendapat dan menghadirkan respons positif siswa [4].

Intelegensi adalah kemampuan yang bersifat umum untuk mengadakan penyesuaian terhadap sesuatu situasi atau masalah, yang meliputi berbagai jenis kemampuan psikis seperti: abstrak, berpikir mekanis, matematis, memahami, mengingat, berbahasa, dan sebagainya [5]. Dalam hal ini adalah Intelegensi (IQ), Intelligence Quotient atau sering 
disebut IQ hanya merupakan nilai atau skor yang diperoleh dari hasil pengukuran kecerdasan atau hasil tes inteligensi. Ada interaksi antara kecerdasan inteligensi (IQ) dan motivasi belajar siswa terhadap prestasi belajar [6]. Sehingga teknik cerdas cermat ini dapat mempengaruhi intelegensi siswa yang mengikuti cerdas cermat tersebut dan meningkatkan motivasi belajar siswa.

\section{Role Play Aplikasi Cerdas Cermat Online Real- time}

\section{Teknik menjawab pertanyaan secara realtime}

Teknik cerdas cermat yang bersifat tatap muka menerapkan babak rebutan. Setiap peserta boleh berebut untuk menjawab pertanyaan yang muncul di layar monitor. Sehingga dengan teknologi realtime pada penelitian ini, menitikberatkan pada pertanyaan rebutan yang bisa dijawab oleh pengguna. Jika seorang pengguna sudah menjawab, maka pengguna yang lain tidak dapat menjawab lagi pertanyaan tersebut.

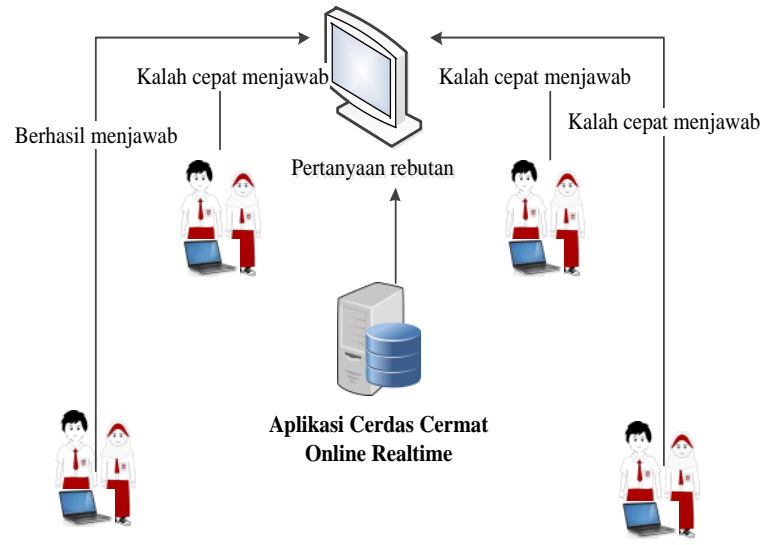

Gambar 2. Requirement Pertanyaan Rebutan.

\section{Leveling}

Aplikasi cerdas cermat tatap muka tentunya selalu dilakukan dengan beberapa leveling atau peringkat. Setiap pengguna (baik perorangan maupun grup/kelompok) yang memenangkan cerdas cermat tersebut pada setiap level akan berkumpul dengan para pemenang lain yang sama-sama memenangkan kompetisi pada level tersebut.

Tantangan dari permainan memiliki efek positif pada pembelajaran baik secara langsung maupun melalui peningkatan keterlibatan. Dalam desain permainan berbasis pendidikan, tantangan permainan harus dapat meningkatkan kemampuan dan belajar pemain untuk mendukung pembelajaran berkelanjutan di permainan berbasis lingkungan belajar [13].

\section{Cerdas cermat online realtime dapat digunakan oleh banyak pengguna}

Aplikasi ini akan terbagi ke dalam berbagai ruang, Istilah ruang dalam setiap grupnya dikenalkan dengan nama lobi. Setiap lobi maksimal saling berkompetisi sebanyak 4 orang/grup. Hal ini mengadopsi cerdas cermat tatap muka yang pada umumnya saling berkompetisi antar kelompok. Berikut arsitektur pada aplikasi cerdas cermat.

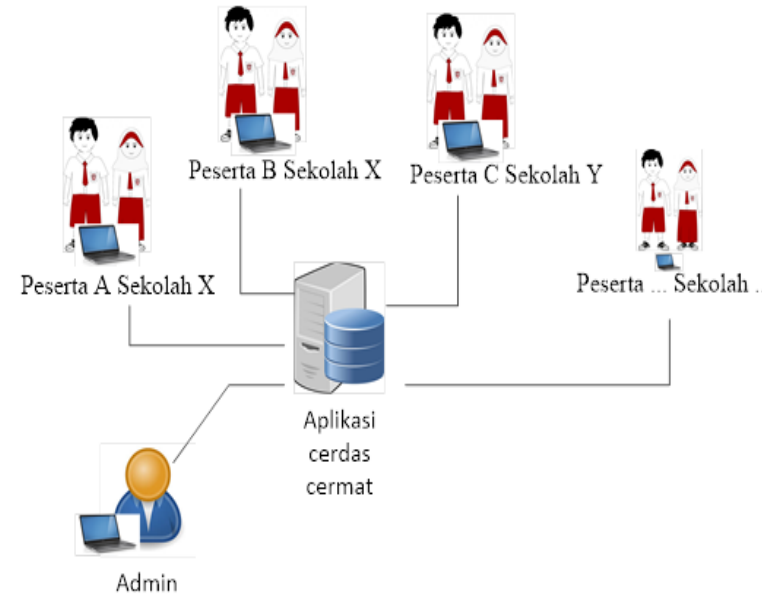

Gambar 3. Arsitektur Aplikasi Cerdas Cermat Online Realtime

\section{Requirement Aplikasi Cerdas Cermat Online}

Berdasarkan role play di atas, maka requirement dapat diidentifikasi sebagai berikut:

Tabel 1. Requirement Aplikasi Cerdas Cermat

\begin{tabular}{cl} 
ID & \multicolumn{1}{c}{ Functional Requirement } \\
\hline Req-1 & Form Lobi tempat dimana nama pemain muncul \\
Req-2 & $\begin{array}{l}\text { Form Soal yang akan dijawab pemain secara } \\
\text { rebutan }\end{array}$ \\
Req-3 & Info mengenai aturan permainan \\
Req-4 & $\begin{array}{l}\text { Pertanyaan yang tampil dikeluarkan secara } \\
\text { random }\end{array}$ \\
Req-5 & User dapat membuat kelompok baru \\
Req-6 & User dapat mengikuti permainan jika sudah \\
& memiliki 4 kelompok \\
Req-7 & Form Peringkat muncul berdasarkan kelompok \\
& yang diikutinya \\
Req-8 & Setiap pemain bisa saling mengenal \\
\hline
\end{tabular}

\section{Prototipe Aplikasi Cerdas Cermat Online Realtime Menggunakan UML}

\section{Use Case Diagram}

Use case diagram menggambarkan hubungan antara aktor (pemain) dengan skenario dalam permainan cerdas cermat sesuai dengan requirement yang didefinisikan. 


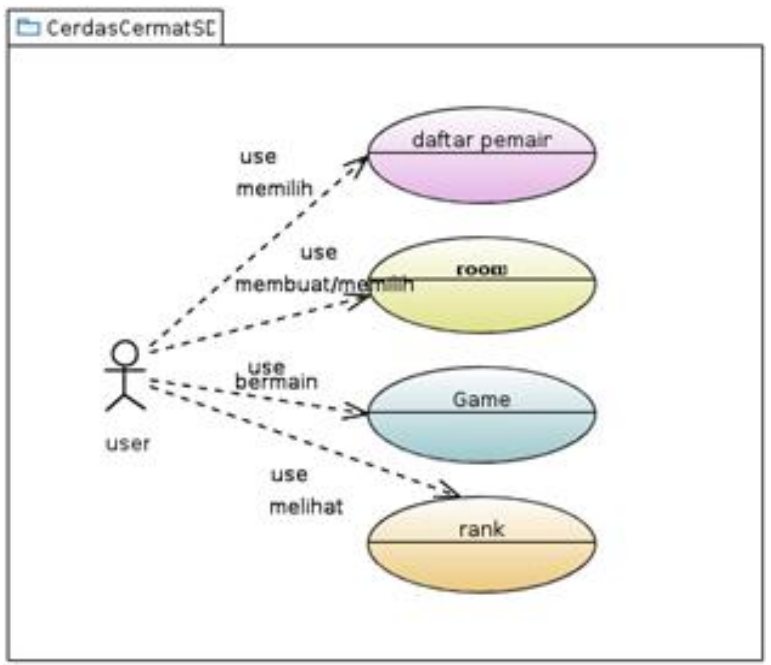

Gambar 4. Use Case Diagram Cerdas Cermat SD

Pada aplikasi yang akan dibangun user/ anak SD memiliki case seperti memilih nama pemain yang sudah terdaftar, kemudian membuat room dan jika pemain dalam room yang sama sudah memenuhi jumlah pemain maksimum maka permainan dalam bentuk soal rebutan akan dilakukan. Permainan berakhir jika soal yang diberikan sudah mencapai nomor yang ditentukan (misal sepuluh soal) dan user diberikan informasi untuk melihat ranking pada tab rank

\section{Class Diagram}

Class diagram menunjukan struktur objek-objek yang terdapat dalam aplikasi, berikut class -class penting yang terdapat pada framework express js. Ketika app.js berhasil diinisialisasikan maka akan terbentuk objek-objek terkait seperti game, player dan routes untuk dapat berinteraksi dengan user.

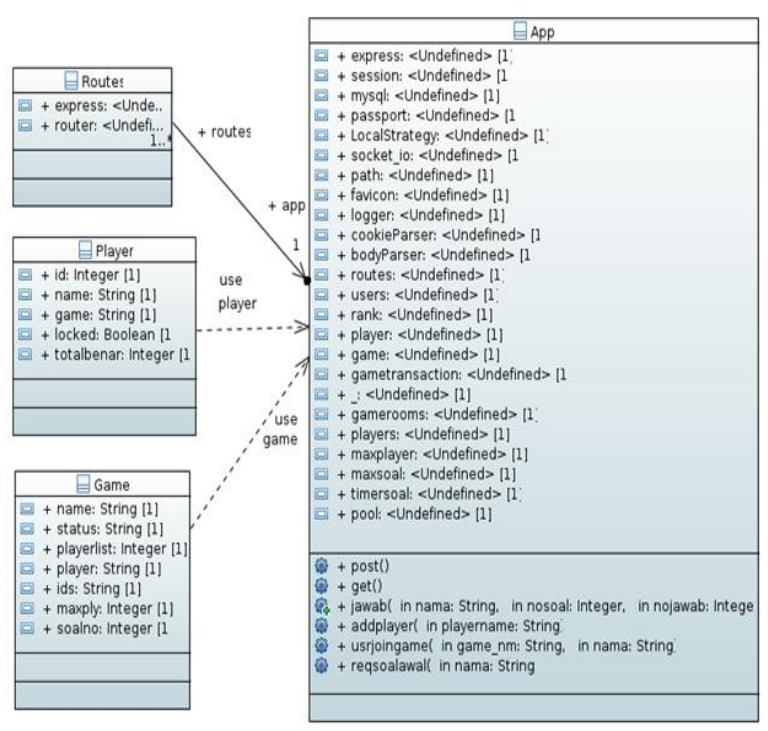

Gambar 5. Class Diagram Aplikasi Cerdas Cernat

\section{Antarmuka Aplikasi Cerdas Cermat Online Realtime}

Aplikasi dibangun dengan menggunakan Node.js. Node.js merupakan salah satu teknologi aplikasi jaringan yang bersifat open source dan dapat berjalan pada bermacam-macam platform. Node.js menggunakan teknik event-driven, non -blocking I / $\mathrm{O}$ model, single thread yang membuatnya ringan dan efisien, sempurna untuk aplikasi real-time, dataintensif yang berjalan pada perangkat terdistribusi [3].

Fungsi layanan yang ada di aplikasi cerdas cermat online realtime adalah sebagai berikut:

a. User Interface (UI) Lobi

b. UI Pertanyaan/soal rebutan (permainan cerdas cermat) dengan input pertanyaan masih dari database

c. UI Peringkat/pemenang dari kompetisi cerdas cermat

Di dalam Lobi para pemain (siswa) dapat memilih pemain lainnya (lawan). Di bawah nama-nama pemain terdapat info terkait dengan aturan main (role play) sebagai panduan dalam bermain cerdas cermat online realtime ini (Gambar 6).

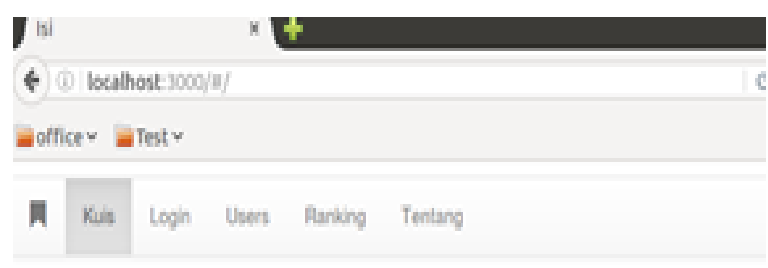

Lobi

\section{Pilih pemain}

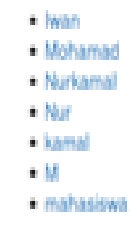

Auran bermain.

- Slaban plih nama dalam list

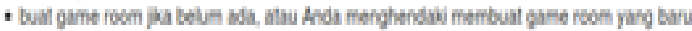

- Pan bergabung dongar room yang dinginan

- Tungog kesiapan selunh perain (mabimum 4 penainj

Gambar 6. Antarmuka Lobi Aplikasi Cerdas Cermat

Soal cerdas cermat yang muncul di layar dijawab secara berebutan, tampilan di layar akan berpindah ke soal berikutnya jika soal rebutan sudah dijawab oleh salah satu pemain (Gambar 7). Di atas soal tersebut disediakan fasilitas chat untuk saling berkomunikasi dengan pemain lainnya. Fasilitas ini diberikan agar setiap pemain bukan hanya saling berkompetisi tetapi juga dapat saling mengenal. 


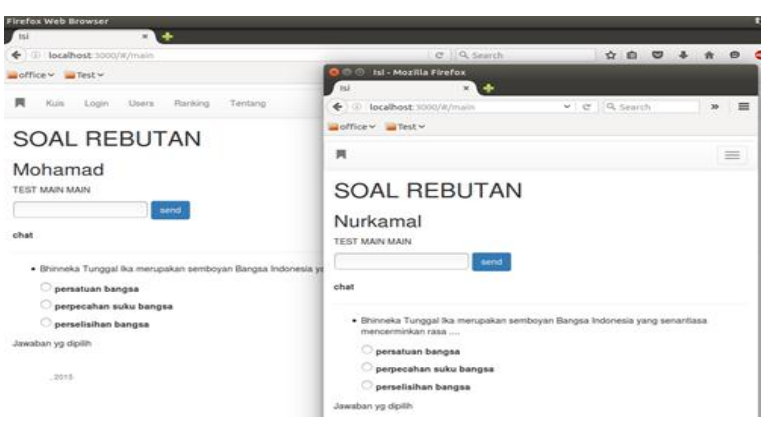

Gambar 7. Antarmuka Soal Rebutan Aplikasi Cerdas Cermat Online Reatime

Fungsi Rank merupakan fasilitas dimana setiap pemain dapat melihat hasil dari permainan cerdas cermat tersebut (Gambar 8).

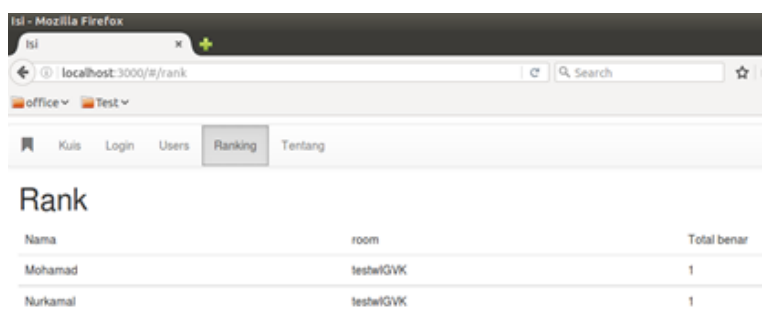

Gambar 8. Antarmuka /Ranking Aplikasi Cerdas Cermat Online Reatime

\section{KESIMPULAN DAN SARAN}

Berdasarkan pembahasan di atas, maka dapat disimpulkan bahwa:

1. requirement aplikasi untuk permainan dalam merangsang minat belajar dan berkompetisi berdasarkan tiga requirement, yaitu teknik menjawab pertanyaan secara realtime, leveling, dan dapat digunakan oleh banyak pengguna.

2. Aplikasi cerdas cermat online realtime diimplementasikan di dalam fungsi pertanyaan babak rebutan.

3. Perilaku kompetisi yang diterapkan dalam aplikasi cerdas cermat online realtime dapat digunakan untuk meningkatkan motivasi belajar, pengetahuan dan kompetisi siswa SD dalam lingkup yang lebih luas

Berdasarkan hasil penelitian ini, maka untuk mendapatkan meningkatkan tingkat kompetisi dan feedback dari orang tua dan masyarakat maupun sekolah, perlu dikembangkan lagi dengan menambahkan fitur leveling sesuai dengan tingkatan kelas di sekolah dasar dan monitoring pada aplikasi cerdas cermat online realtime. Monitoring ini dapat digunakan sebagai nilai tambah dan penghargaan (reward) bagi sekolah maupun masyarakat kepada para siswa yang berkompetisi di dalamnya.

\section{UCAPAN TERIMA KASIH}

Terimakasih kepada Ristek Dikti yang telah memberikan dana penelitian dosen pemula sehingga terlaksananya penelitian ini.

\section{DAFTAR PUSTAKA}

[1]. Kemdiknas.go.id (2012), Sekolah Dasar, http:// www.kemdiknas.go.id/kemdikbud/peserta-didiksekolah-dasar, diakses 6 April 2015

[2]. Kamus Besar Bahasa Indonesia, cerdas, http:// badanbahasa.kemdikbud.go.id/ kbbi/index.php, diakses 6 April 2015

[3]. Letaifa, Nagi, 2011, A Full Javascript Architecture, Part One - NodeJS, http://blog.zenika.com/ index.php?post/2011/04/10/NodeJS, diakses tanggal 11 Juni 2015

[4]. Firdaus, Taufik, 2012, Model Pembelajaran Menyampaikan Pendapat Dalam Pembelajaran Berbicara Dengan Menggunakan Teknik Cerdas Cermat Pada Siswa Kelas Viii Smpn 2 Banyuresmi , Skripsi Program Studi Pendidikan Bahasa Dan Sastra Indonesia Sekolah Tinggi Keguruan Ilmu Pendidikan (STKIP) Siliwangi Bandung

[5]. Dalyono, 2004, Psikologi Pendidikan, Jakarta: Rineka Cipta.

[6]. Mu'asomah, Syefti Anisatul, 2014, Pengaruh Kecerdasan Inteligensi (Iq) Dan Motivasi Belajar Siswa Terhadap Prestasi Belajar Fiqih Siswa Kelas Xi Madrasah Aliyah Negeri 1 Tulungagung Tahun Ajaran 2013/2014. Skripsi Jurusan Pendidikan Agama Islam Fakultas Tarbiyah Dan Ilmu Keguruan Institut Agama Islam Negeri (Iain) Tulungagung 2014

[7]. Pressman, R. S. 2001. Software Engineering - A Practitioner Approach. New York: Mac GrawHill Higher Education.

[8]. Alan Amory, Kevin Naicker, Jacky Vincent dan Claudia Adams (1999). The use of computer games as an educational tool: identification of appropriate game types and game elements. British Journal of Educational Technology Vol. 30 No. 41999.

[9]. I Wayan Budiana (2014). Skripsi Penggunaan teknik cerdas cermat untuk meningkatkan kemampuan menyampaikan pendapat dalam pembelajaran berbicara siswa kelas VIII.3 SMP laboratorium Undiksha Singaraja tahun pelajaran 2012/2013.

[10]. Marina Papastergiou (2009). Digital GameBased Learning in high school Computer Science education: Impact on educational effectiveness and student motivation, Computer \& Education journal homepage: www.elsevier. com/locate/compedu. doi:10.1016/j.compedu. 2008.06.004 
[11]. Burguillo, Juan C. 2010. Using game theory and Competition-based Learning to stimulate student motivation and performance. Computers \& Education. DOI: 10.1016/j.compedu.2010. 02.018 .

[12]. Ogedebe, Peter M. Jacob, Babatunde Peter. 2012. Software Prototyping: A Strategy to Use When User Lacks Data Processing Experience. ARPN Journal of Systems and Software VOL. 2, NO.6, JUNE 2012 ISSN 2222-9833.
[13]. Juho Hamari, David J. Shernoff, Elizabeth Rowe, Brianno Coller, Jodi Asbell-Clarke, Teon Edwards (2015) Challenging games help students learn: An empirical study on engagement, flow and immersion in game-based learning. Computer in Human Behavior. journal homepage: www.elsevier.com/locate/comphumbeh

[14]. Eriksson, H., Penker, M., Lyons, B., dan Fado, D. (2004) :UML 2 Toolkit, Indiana :Wiley Publishing, Inc.

[15]. https://nodejs.org, diakses 6 April 2015. 